\title{
University-school cooperation: Perspectives of pre-service teachers, practice teachers and faculty members
}

\author{
Sultan Selen Kula ${ }^{1 *}$, Mutlu Pınar Demirci Güler ${ }^{2}$ \\ ${ }^{12}$ Faculty of Education, Educational Sciences, Kirsehir Ahi Evran University, Turkey \\ selen.yazgunoglu@ahievran.edu.tr ${ }^{*}$ \\ pinarguler@ahievran.edu.tr \\ *Corresponding Author
}

https://doi.org/10.24191/ajue.v17i1.12620

Received: 7 October 2020

Accepted: 22 January 2021

Date Published Online: 8 March 2021

Published: 8 March 2021

\begin{abstract}
The research aimed to determine the views and expectations of pre-service teachers studying in the field of classroom teaching, because practice teachers in practice schools, and faculty members are responsible for courses related to teaching practice regarding teaching practice processes. The research was designed as a case study from qualitative research designs. The study group consists of three groups. The first group consists of 36 females and 9 males, aged between 21 and 25, totally of 45 pre-service teachers. The second group consists of 16 females and 30 males, aged between 30 and 51, totally of 46 practice teachers. The third group consists of 4 females and 7 males, aged between 30 and 51 , totally of 11 faculty members. The data was collected in writing with separate forms for pre-service teachers, practice teachers, and faculty members. The data was analyzed by thematic analysis. The results of the research suggest that the existing operation regarding the university-school collaboration is insufficient and those pre-service teachers have the expectation to increase the practice courses in terms of number and duration. It is thought that the interaction between the university and the school should be improved in all aspects. This research is expected to be a guide for revealing expectations of related parties and improving the process during the teaching practice.
\end{abstract}

Keywords: Pre-service teacher, Teacher training, Teaching practice, University-school cooperation.

\section{Introduction}

The rapid progress of scientific and technological developments has made it imperative that societies adopt a structure that can control change rather than adapting to this rapid change, so expectations for education, training, and teachers have changed over time. Developed countries have adopted strategies for identifying and resolving problems in the field of teacher training in a significant part of their educational activities, and in this context, traditional approaches, which are insufficient to adapt to the age in teacher training, have been replaced by new practices that have been developed in line with scientific research to allow teachers to meet the needs of the age.

Teacher training programs are staged as; the selection of pre-service teachers, education within the program of faculties of education (pre-service training), the appointment to the profession, and training of teachers on the job (in-service training). The teacher training process aims to integrate theoretically and applied courses and ensure that pre-service teachers are equipped with various knowledge, skills, and attitudes towards the profession. Based on university-school collaboration, an effective and productive structure of teaching practice courses in the pre-service education process is an important factor to train successful teachers (Akdemir, 2013). Learning takes place by applying and integrating knowledge into the real world, and most teaching theories require knowledge and skills to be applicable for effective learning (Merrill, 2002). By their nature, teaching practice courses focus on 
creating ground for mutual exchange of ideas, interaction, and discussion between pre-service teacher, practice teacher, and faculty member to improve teaching attitudes of all parties. Offering various practice opportunities to pre-service teachers to apply their knowledge in meaningful contexts is important in the process of gaining the "teaching" phenomenon (Zanting, Verloop, \& Vermunt, 2001).

Teaching practice lesson that provides university-school cooperation is not a one-way process that supports the development of pre-service teachers, but also an opportunity for teachers and faculty members to update their knowledge and be aware of the innovations brought by the era. The benefits of university-school cooperation in teacher training show distribution in many different fields. Edelfelt and Coble (2004) listed the most important ones as follows: Increasing and strengthening practice-based teaching experiences, examining learning tools, reducing cultural differences between teachers and academics, developing teacher roles in teacher training, encouraging academics that engage in arts and science to work with teachers, encouraging new teachers, and using technology in teacher training. Furthermore, many studies suggest that the guidance of teachers greatly affects the professional development of pre-service teachers studying at universities (Healy, Ehrich, Hansford \& Stewart, 2001; Saka, 2019; Toll, Nierstheimer, Lenski, \& Kolloff, 2004). It is also stated that university-school cooperation within a specific program increases the professional development and learning levels of students, teachers, and faculty members (Grudnoff, Haigh \& Mackisack, 2017).

University-school cooperation models in the literature suggest that the increasing role of practice schools in this process is noteworthy, and it is seen that practice schools are academically planned and regularly supported by the university (Maandag, Deinum, Hofman, \& Buitink, 2007; Xie \&Huijser, 2020). In this context, it seems possible to say that the role of practice schools and practice teachers will become more active and important in the teacher training process in the future.

\subsection{University-school cooperation in teacher training programs in Turkey}

According to Global Teacher Status Index (Global Teacher Status Index, 2018), Turkey ranks 7 th among 35 countries in the world in terms of value given to teachers. The university-school practice courses, which take place in the training process of the highly valued teaching profession, are extremely important in terms of professional development.

In the updates made by the Ministry of National Education in 2017, three competency areas are defined under the scope of "General Competencies for Teaching Profession"; "professional knowledge", "professional skill", "attitude and values". These competency areas and general qualifications are given in Table 1 (Ministry of National Education [MoNE], 2017):

Table 1. General competencies for the teaching profession

\begin{tabular}{lll}
\hline A. Professional Knowledge & B. Professional Skill & C. Attitude and Values \\
\hline A1. Field Knowledge & B1. Education Planning & $\begin{array}{l}\text { C1. National, Moral and } \\
\text { Universal Values }\end{array}$ \\
$\begin{array}{l}\text { Has advanced theoretical, } \\
\text { methodological, and factual } \\
\text { knowledge to cover the }\end{array}$ & $\begin{array}{l}\text { Plans education and training } \\
\text { processes effectively. }\end{array}$ & $\begin{array}{l}\text { Takes national, moral, } \\
\text { and universal values into } \\
\text { consideration. }\end{array}$
\end{tabular}

inquisitive perspective in the field.

A2. Field Education B2. Creating Learning Environments

Knowledge

Has education program and pedagogical content knowledge.

\section{A3. Legislation Knowledge}

Prepares healthy and safe learning environments and appropriate teaching materials for all students where effective learning can take place.

B3. Managing the Teaching and C3. Communication and Learning Process

\section{C2. Approach to Student}

Displays a supportive attitude towards students' development.

Cooperation 
Acts by the legislation regarding duties, rights, and responsibilities as an individual and teacher.
Carries out the teaching and learning process effectively.

\section{B4. Assessment and Evaluation}

Uses assessment and evaluation methods, techniques, and tools appropriately.
Establishes effective

communication and

cooperation with

students, colleagues, family, and other parties of education.

C4. Personal and

Professional

Development

By self-evaluation, participates in studies for personal and professional development.

Defined competency areas set standards for training teachers with desired qualities and serve as a reference for the regulation of the curriculum of higher education institutions in Turkey. Within the framework of these competencies, theoretical and applied courses are renewed and updated. The "School Experience" course, which was being applied until 2018, has been abolished due to the failure to perform functionally and effectively and by combining the content of this course, the Teaching Practice course has taken place in two periods as Teaching Practice 1 and Teaching Practice 2 in all programs (Higher Education Board [HEB], 2018).

In the first semester of the fourth grade, pre-service teachers take the course called Teaching Practice-1, consisting of two hours of theoretical content in the faculty and six hours of practice in the practice school per week. In this course, the pre-service teacher is expected to determine the work in the practice school within a day, prepare a daily plan (prepare the environment, materials, and assessment tools required by the plan), apply the plan or some activities from the plan, prepare a plan to manage unwanted behavior of a student, prepare a self-evaluation report about the practice and prepare a portfolio that includes all the processes. In the last semester at the university, the pre-service teacher takes the course Teaching Practice-2, which also consists of two hours of theoretical content in the faculty and six hours of practice in the practice school. In this course, the pre-service teacher is expected to prepare a daily plan every week, apply the prepared plan, evaluate the practice with the practice teacher and faculty member, make corrections and reapply, and prepare a portfolio that includes all the processes.

Generally speaking, within the scope of the updated program, a pre-service teacher studying in the field of classroom teaching takes teaching practice lessons in both the first and second semesters of the fourth grade during the four-year undergraduate education. These courses aim to make the preservice teacher take on the teacher role cognitively, affectively, and increasingly by using lesson plans and teaching materials. Pre-service teacher is evaluated by practice teacher and faculty member at the university through an online system (Practice Student Evaluation System) affiliated to the Ministry of National Education.

\subsection{The importance and aim of the study}

An examination of the results of studies conducted on university-school cooperation in Turkey between 2000-2010 shows that in approximately $60 \%$ of the results (22 out of 36 studies), people involved in teaching practice reported negative opinions (Kasapoğlu, 2015). It is stated that the most basic deficiency of teaching practices is that the university-school cooperation process cannot be carried out effectively (Arkün-Kocadere \& Aşkar, 2013; Kudu, Özbek \& Bindak, 2006) and that scientific studies are needed to determine the expectations of all parties about university-school cooperation (Atmiş, 2013; Boreen, 2009). It is noteworthy that there are not enough studies involving the views of practice teachers, pre-service teachers, and faculty members engaged in the process. With the cooperative work of practice teachers, faculty members, and pre-service teachers, practice models that increase professional development and learning can be created (Grudnoff, Haigh \& Mackisack, 2017). In this context, it was aimed to determine the views and expectations of the pre-service teachers in the field of classroom teaching, teachers at practice schools, and faculty members responsible for teaching 
practice courses. For this purpose, research problems were determined as follows: What are the views of pre-service teachers, practice teachers, and the faculty members regarding university-school cooperation?

\section{Method}

\subsection{Research model}

In this study, which aimed to reveal the views and expectations of pre-service teachers, practice teachers, and faculty members regarding the university-school cooperation process, the case study was used. Case study, which is one of the qualitative research methods based on an in-depth description and analysis of the situation (Creswell, 2015; Merriam, 2013). Thus, this design provides researchers with the opportunity to examine real-life events closely in a certain context (Yin, 2003). In this research, the "situation" was determined as the participants' definition of the university-school cooperation process.

\subsection{Study group}

Criterion sampling was used in forming the study group of the research (Patton, 1990). In this sampling method, the study group was formed by determining the criteria that were considered to be important. The first criterion was choosing participants who were actively involved in the process of university-school cooperation which refer pre-service teachers. The second group refers to practice teachers who were working in the field of classroom teaching. The third group are referred to faculty members who were carrying out the practice courses in the department. Accordingly, there were 45 preservice teachers, 46 practice teachers, and 11 faculty members participating in the study. Pre-service teachers consisted of a total of 45 people, 36 females, and 9 males. Among them, 12 of the pre-service teachers were third grade and 33 were fourth grade, their ages were between 21-25. However, for the second group, 16 of the practice teachers were females, 30 were males, their seniority varied between 10-31 and above, and their ages were between 30-51 and above. For the third group of faculty members, 4 of the faculty members were female and 7 of them were male. Their seniority varied between 5-31 and above, and their ages varied between 30-51 and above.

\subsection{Data collection and analysis}

Separate forms have been created for pre-service teachers, practice teachers, and faculty members to collect data. The literature on university-school cooperation was scanned, and after obtaining comprehensive information, open-ended questions were created for the study group. To ensure the content validity of each of the draft forms, expert opinions were received from three faculty members from the field of classroom teaching and two faculty members from the field of educational sciences. Accordingly, necessary arrangements have been made and each form has been tested with a person who met the criteria in the study group to ensure the clarity of the questions. The forms consisted of two parts. In the first part, some questions provided information gathering about the participants, and in the second part, there were open-ended questions aimed to determine the views and expectations of the participants regarding university-school cooperation.

During the data collection, necessary explanations were made to the participants, and information was given about the study. The collection of data varied between 20-30 minutes. All participants in the research were voluntarily involved in the process.

The data were analyzed by the thematic analysis method. The research data were categorized through certain themes, sub-themes, and codes (Yildırım \& Şimşek, 2008). The names and order of the pre-service teachers (in Turkish; "öğretmen adayı") in the study were coded as "ÖA1 ... ÖA45", practice teachers (in Turkish; "öğretmen") as "Ö1 ... Ö46" and faculty members (in Turkish; "öğretim elemanları") as "ÖE1 ... ÖE11".

\subsection{Validity and reliability of the study}

In qualitative research, the concept of reliability is evaluated with the attention in the design and implementation stages of the research. The concepts of credibility, transferability, reliability, and 
verifiability used in qualitative research are expressed with the concepts of internal validity, external validity, reliability, and objectivity in quantitative research (Merriam, 2013). To ensure the credibility of the research, expert opinions regarding the opinion forms were received and necessary arrangements were made. As another measure, direct views of the participants were included in the study findings. The purposeful sampling method was used to ensure transferability and attention was paid to include all details about the research process in the research report (Lincoln \& Guba, 2013). To ensure the reliability of the research, each researcher first coded individually and then came together and shaped the analysis process by reconciling together. Furthermore, clearly determining the role of the researcher in the research and expressing it in detail was another measure taken to increase reliability (Miles \& Huberman, 1994). In this research, researchers actively participated in all processes. While collecting the data, they informed the participants about their specialties and the purpose of the research. In all the processes from the design of the research to its reporting, the researchers constantly reviewed the integrity and consistency of the research.

\section{Findings}

The expectations of pre-service teachers, practice teachers, and faculty members responsible for teaching practice courses are listed in this section under separate headings.

\subsection{Expectations of pre-service teachers regarding university-school cooperation}

Expectations of pre-service teachers participating in the study regarding university-school cooperation were grouped under 6 themes. These themes were grouped as "expectations from the school management in practice schools, expectations from the practice teacher, expectations from the advisor faculty member, expectations from the university, expectations from the university-school cooperation". Findings regarding each of these themes are included in separate titles below.

\subsubsection{Expectations of pre-service teachers from school management in practice schools}

The expectations of pre-service teachers studying in the field of classroom teaching were grouped in seven sub-themes as "communication, practice process, physical facilities, evaluation, establishing coordination with parents, social and cultural events, supporting professional development". The most frequently expressed expectation was being perceived and valued as a colleague by the school management. For example, a pre-service teacher with code ÖA31 expressed this expectation as follows: "I expect the principal to show us, interns, the respect that is shown to other teachers. I would like him to evaluate my requests about the class, to evaluate my demands".

Pre-service teachers had expectations from school management in terms of communication. Interest, understanding, effective communication, respect, and a problem-solving attitude were among them. Pre-service teachers also wanted to practice at every grade in practice schools. The pre-service teacher coded ÖA20 stated that working with students and different teachers at each grade would benefit them professionally: "to help me see the education at all grades, to direct me to teachers who can benefit me, to give me the necessary information about the school".

Another important expectation of pre-service teachers from school management was getting information about practice processes. Pre-service teachers did not want to hesitate about what they should or should not do in their practice schools. For example, a teacher candidate with code ÖA3 said: "In some cases, they should provide precise information, officially inform us what we should or shouldn't do in the internship."

The pre-service teachers had expectations from school management in terms of physical facilities. These expectations were stated as providing physical opportunities related to the teaching process in the classrooms. Also, pre-service teachers expected school management to inform them about the Ministry of National Education's Practice Student Evaluation System. For example, a pre-service teacher coded ÖA5 said, "He can plan different activities for us to develop more. For example, nothing related to the Ministry of National Education system was shown. Our development was not handled entirely". In addition to all these expectations, there were expectations regarding parents, social and cultural events, and evaluation processes. 


\subsubsection{Expectations of pre-service teachers from practice teachers in practice schools}

The expectations of pre-service teachers were grouped in four sub-themes as "communication, practice process, evaluation and supporting professional development". The most basic expectation of pre-service teachers from teachers in practice schools was to share their experiences with them. The expectations were intended for both in planning and relation to student and parent communication. For example, a pre-service teacher coded ÖA3 said "He should give us some information that will help us practice our profession, and give us tips and technical information about the problems we may encounter in the future. He should structure our lecturing by giving feedback".

Other pre-service teachers had similar views on this sub-theme. Another expectation that preservice teachers considered important was the support and guidance of practice teachers. Pre-service teachers also expected practice teachers to handle feedbacks and evaluations effectively. In this context, pre-service teachers emphasized the importance of the practice teachers observing them during the lecture and making constructive criticism. For example, a pre-service teacher coded ÖA3 said, "He should give us some information that will help us practice our profession, and give us tips and technical information about the problems we may encounter in the future. He should structure our lecturing by giving feedback". Pre-service teachers emphasized that these feedbacks and corrections should not be made during the lecture, but later by meeting one-on-one. Some pre-service teachers even stated that they were uncomfortable with the intervention of the practice teacher.

Pre-service teachers had expectations from practice teachers, as well as from school management, about accepting and respecting them as teachers. In this context, pre-service teacher coded ÖA43 said, "I expect them not to adopt the teachers' room as their own home, to introduce us as a teacher, rather than a big brother or sister in the classroom, to tell their students that we have all the authority when they leave the classroom, not to stand in a corner while we are lecturing and not to compare us with other pre-service teachers, and not to leave the school when they leave the class to us".

\subsubsection{Expectations of pre-service teachers from advisor faculty members}

The expectations of pre-service teachers from faculty members were grouped in three subthemes as "communication, practice process, and evaluation". Pre-service teachers had expectations from faculty members to support and guide their development in the context of communication. Preservice teachers expected faculty members to have effective and active communication with both the practice schools and pre-service teachers. They expected the faculty members to visit the practice schools more frequently and cooperate effectively. For example, pre-service teacher coded ÖA8 said, "We expect them to be in contact with us and to come to our schools in some cases." emphasizing school visits.

The most frequently expressed expectation in all sub-themes was that the faculty members should go to practice schools more frequently, stay in communication with the school, teachers, and pre-service teachers and contribute by observing the process. The pre-service teacher coded ÖA26 said, "I would like the responsible faculty member to inform us about what we can do every week. I would like him to meet with our practice teacher and get information, even if he is not observing the process at school. I would like the responsible faculty member to communicate more with us and guide us".

The pre-service teachers considered teaching practice as an important process for professional development that should be focused on their development rather than evaluating the process for grading. The pre-service teacher coded ÖA31 said: "I would like him to come and watch us at certain times. He should explain how we should overcome our deficiencies rather than grading us. He should indicate our expected outcomes and what we should do from the beginning of the year". Pre-service teachers also expected faculty members to share their experiences, to evaluate the reports with understanding, to make video recordings to evaluate, and to share information by organizing frequent meetings.

\subsubsection{Expectations of pre-service teachers from the university}

The expectations of pre-service teachers were grouped in five sub-themes, "communication, planning of practice process, practice process, supporting professional development and practice 
schools". The highest expectation of pre-service teachers from the university was to increase the number and duration of practice courses. The pre-service teacher coded ÖA13 said, "The time and duration of the internship is very low. There should be an internship from the 2nd grade, not only the 4th grade". Among the pre-service teachers, there was an expectation for the field teaching lessons to be taught in elementary schools as applied. For example, a pre-service teacher coded ÖA31 said, "I think the internship should be done in the 2nd or 3rd grade, not only in the 4th grade. Practice should be done several times a week, for example, mathematics teaching and science teaching should be done in practice schools. We should be asked to practice".

Pre-service teachers expected support from the university for transportation. Pre-service teachers who have transportation problems expected the transportation of the students to be taken into consideration in determining the practice schools or that the universities provide transportation.

Another important expectation was the university's multi-faceted communication with the National Education Institutions and pre-service teachers, and playing the role of a bridge. The communication sub-theme draws attention as an area that all parties have expectations for.

Good planning and control of processes related to teaching practice was another expectation of pre-service teachers. Pre-service teachers expected the university to provide clear information, hold seminars and observe the process. Pre-service teachers also expected to find the opportunity to practice in different types of schools such as village schools, schools with a combined class, and qualified schools.

\subsubsection{Expectations of pre-service teachers from university-school cooperation}

The expectations of pre-service teachers from the university-school collaboration were grouped in four sub-themes, "collaboration, practice process, evaluation and practice schools". Expectations of pre-service teachers from university-school cooperation focused on more frequent and regular communication. Pre-service teachers expected regular interaction and communication between university and school. They emphasized that this link should be used for mutual exchange of views and determining common attitudes. The pre-service teacher coded ÖA4 expressed this expectation by saying: "I would like to have a closer connection between the university and the school. I want a university that supports its students and a school that responds to it". The pre-service teacher coded ÖA14 also said: "University-school cooperation should be consistent. The rules given by the university should not contradict the school." stating the expectation regarding the consistent and common attitude between the two institutions. The pre-service teacher coded ÖA30 said, "I would like the teachers who work at the practice schools and faculty members to get together and determine what we should do for the term." stating that the practice teacher and faculty member should meet to determine common attitudes.

Similar to the findings in other themes, it was seen that pre-service teachers had the expectation to be accepted as a teacher and a colleague. Another one of the expectations that pre-service teachers often expressed was to minimize the practice differences between practice schools, that a common decision regarding the activities should be implemented. The pre-service teacher coded ÖA24 said, "...I also expect the same practice to be valid in all schools. Because some of the practice schools challenge the students, others let them slack off".

The pre-service teachers expected the university and the school to reach an agreement about the flexibility for absenteeism in the case of compulsory situations. The pre-service teachers also expected to see a common, disciplined, and problem-solving attitude from both university and school towards issues related to practice.

\subsection{Expectations of practice teachers from university-school cooperation}

Expectations of practice teachers regarding university-school cooperation were grouped under 5 themes; "expectations from school, expectations from university, expectations from the Ministry of National Education, suggestions and operational considerations". Findings regarding each of these themes are included in separate titles below. 


\subsubsection{Expectations of practice teachers from schools for their professional development}

The most important expectation of practice teachers from the school was to provide opportunities for in-service training and seminars to ensure their professional development. For example, the teacher coded Ö23 said: "Planning teacher seminars by the purpose, and covering the issues about the problems that may be encountered during the year. Effective training between specific groups in schools or provinces where teacher participation has been increased rather than in-service training activities that have gone far from its purpose". It was noteworthy that teachers expected the seminars at the beginning and end of each semester to be functional, up-to-date, and effective.

The improvement of the physical facilities, infrastructure facilities, and technical equipment of the schools was among the important expectations of the teachers. Teacher coded Ö24 stated this expectation as follows: "The physical environment of the school should be better to achieve professional development. Schools should have sections such as a gym, meeting room, dining hall, and library. In schools, importance should also be given to social and sports events besides lessons".

Teachers stated that school management should demonstrate a fair and democratic attitude that provides an atmosphere of trust in the school. Also, the school management was expected to work in cooperation with teachers and motivate them professionally. It was stated that effective communication and peace environment in school culture would also affect teachers positively.

\subsubsection{Expectations of practice teachers from the university regarding their professional development}

Teachers expected universities to organize scientific events for their professional development. During the seminar periods, they expected the faculty members to share up-to-date information and exchange ideas. The teacher coded Ö25 said, "Since teaching is everchanging, open to innovation, and the scientific developments are continuous, universities should inform us about developments and innovations, publish magazines containing changes and innovations and forward them to all teachers and include sections containing teachers' views in these magazines." stating the expectation for being informed about scientific studies and being involved in scientific study processes. Many teachers expected an increase of the practice hours of pre-service teachers in schools. The teacher coded Ö34 said; "Intern students should come to school 3-4 days a week instead of once a week, support during school trips, exchange views with teachers who have made a name in their career". Teachers stated that spending more time in practice schools, observing many different processes related to education, and participating in these processes would contribute to the professional development of pre-service teachers.

Practice teachers are expected to communicate with the faculty members and be a part of the primary school program development process. For example, the teacher coded Ö3 said, "Universities should be in constant cooperation with schools and teachers. Cooperation with teachers should be made about program development, following new developments and teacher training."

\subsubsection{Expectations of practice teachers from the ministry of national education regarding professional development}

Practice teachers expected MoNE to organize qualified and need-oriented in-service training. They expected regular in-service training by expert instructors. The teacher coded Ö43 said, "Development, research, and information-based seminars, courses and training should be provided. Every branch should be brought together with monthly meetings. Information should be exchanged". Practice teachers also stated that primary school programs should not be changed frequently as this frequent change affects the education process negatively. They drew attention to the importance of the views of teachers who are practicing in this field during the development of educational programs. The teacher coded Ö5 said, "I want them to get the views of our teachers before making a change in the educational activities, and decide whether or not to make changes accordingly. I believe MoNE should get away from "we did it like this" attitude. If I'm to give an example, I can mention the handwriting system." expressing that the decisions taken without consulting teachers' views would not be effective. 
Practice teachers stated that they expected the improvement of personal rights and economic conditions. They also expected MoNE to show that the teacher is valued more at the ministry level. Teachers expected a fair approach in terms of assignments and conditions for being a manager in schools. This expectation was stated by the teacher coded Ö42 who said, "Politics should withdraw from schools. No more favoritism".

\subsubsection{Suggestions of practice teachers for university-school cooperation}

Practice teachers suggested that pre-service teachers should practice more in schools as part of university-school cooperation. They thought that this would help pre-service teachers to associate the theoretical knowledge with real-life and develop professionally. The teacher coded Ö41 said, "I would like to see more of the interns at the school. Learning takes place with practice".

The highest expectation of practice teachers from university-school cooperation was to increase scientific sharing with conferences and workshops. Teachers wanted to benefit from the knowledge and experience of faculty members and also to share their own with pre-service teachers by visiting the university. In other words, they expected mutual sharing and interaction. The teacher coded Ö42 expressed it as follows: "The main factor in university-school cooperation is active teachers, and thus, teachers in schools should stand out rather than faculty members. It should not be forgotten that the university takes part only in teachers' academic stages. We should participate more in university education. We should not only send interns to schools but also send practice teachers to universities from time to time."

Practice teachers argued that university-school cooperation should not be limited to the process of pre-service teachers coming to practice schools. They emphasized the necessity of regular and planned exchange of views and information between teachers and faculty members. They thought that this sharing would not be possible in a one-way perspective where only the university is viewed as an informative institution. They also emphasized that teachers would contribute professionally to both university students and faculty members.

Practice teachers suggested the establishment of practice and project schools in education faculties so that both pre-service teachers and faculty members are constantly aware of the field of application. Practice teachers thought that faculty members were disconnected from real life.

\subsubsection{Evaluation of practice teachers of existing process regarding university-school cooperation}

Practice teachers were asked to evaluate the existing cooperation between universities and schools. The findings suggested that practice teachers mostly evaluated the existing situation negatively and wanted to increase the cooperation between the university and the school. It was observed that the teachers felt uncomfortable with the fact that the only thing they have in common with the faculties of education is the internship process and that they wanted to have more interaction. For example, the teacher coded Ö42 said, "I have never seen such cooperation. Sending trainee students to practice schools is more of an application rather than cooperation. Cooperation is collaborative work. We could not see the university at any stage, only the students are coming, we help in terms of experience. Just a one-sided study". Regarding the teacher training process, practice teachers expected the faculty members to come to schools more often, observe and guide the pre-service teachers.

\subsection{Expectations of faculty members regarding university-school cooperation}

Expectations of faculty members who participated in the research regarding university-school cooperation were grouped under 6 themes. These themes were grouped as "faculty member's attendance at school, teacher and manager attitudes, pre-service teachers' responsibilities, process evaluation, expectations, and methods of evaluating practice". Findings regarding each of these themes are given in separate titles below. 


\subsubsection{Faculty members' attendance at school}

Most of the faculty members in the study stated that they went to practice schools four times during the twelve-week teaching practice. They often found the frequency of going to practice schools insufficient. The reasons for the faculty members' failure to attend practice schools sufficiently were; the excess course load at the university, the academic studies carried out outside of the courses, management responsibilities, lack of time, and the intention of not overwhelming the schools. Also, some faculty members evaluated their frequency of going to practice schools as sufficient $(f=4)$.

\subsubsection{Perceptions of faculty members regarding teacher and manager attitudes}

Faculty members stated that they encountered mostly positive teacher and manager attitudes at practice schools $(\mathrm{f}=14)$. It was stated that teachers and managers were positive $(\mathrm{f}=6)$, interested in themselves and practice students $(\mathrm{f}=4)$, friendly $(\mathrm{f}=1)$, helpful $(\mathrm{f}=1)$, moderate $(\mathrm{f}=1)$, and open to academic sharing $(\mathrm{f}=1)$. Some faculty members stated that teachers and managers had a reproachful attitude as faculty members attended practice schools only to run their own academic affairs or not attended enough $(\mathrm{f}=2)$. For example, the faculty member coded ÖE5 said: "It is also possible to say that managers generally have a reproachful attitude towards faculty members. They demand us to come to schools more". It was also stated that among teachers and managers, some do not show enough interest $(\mathrm{f}=1)$, see activities related to university-school cooperation as drudgery $(\mathrm{f}=1)$ and do not want faculty members to come to schools $(\mathrm{f}=1)$.

\subsubsection{Perceptions of faculty members regarding responsibilities of pre-service teachers}

The faculty members stated that pre-service teachers took sufficient responsibility in their teaching practices and met the expectations $(\mathrm{f}=13)$. It was stated that the guidance of the faculty member was important $(\mathrm{f}=2)$. For example, participant coded ÖE10 said, "... I think we achieve very good results when we provide good guidance". It was stated that pre-service teachers' anxieties about the exam (KPSS) for being appointed as a teacher prevented them from taking sufficient responsibility in their teaching practices $(\mathrm{f}=3)$. The faculty member coded ÖE3 expressed this as follows: "The priority of the fourth-grade students is KPSS, so this course does not achieve its purpose completely". It was also stated that some of the students' not internalizing being a teacher $(\mathrm{f}=1)$, being uninterested $(\mathrm{f}=1)$, and focusing on other courses at university $(f=1)$ prevented them from performing enough in teaching practices.

\subsubsection{Evaluations of faculty members regarding existing university-school cooperation}

The faculty members generally evaluated the university-school cooperation as negative ( $\mathrm{f}=13)$. It was stated that there was no effective communication and functional cooperation process between institutions ( $\mathrm{f}=5)$. The faculty member coded ÖE5 said, "I think there is no effective communication between the university and the school. I think that regular meetings should be exchanged at regular intervals and within the framework of predetermined issues...". Faculty members stated that the online system that evaluates pre-service teachers was not appropriate $(\mathrm{f}=3)$. The faculty member coded ÖE3 drew attention to this situation by saying "MEBBIS thing should either be terminated or the parties should understand this job correctly ...". According to the faculty members, both institutions perceived and evaluated the process of cooperation differently $(\mathrm{f}=2)$. The importance of establishing partnerships in practices by reaching a consensus among institutions was also emphasized. It was stated that by doing this, the perfunctory practices $(\mathrm{f}=1)$ would be eliminated. Some faculty members thought that the process was developing $(\mathrm{f}=1)$ or that it was already an appropriate process $(\mathrm{f}=2)$.

\subsubsection{Expectations of faculty members regarding university-school cooperation}

The most basic expectation of faculty members regarding the university-school cooperation was to organize meetings with teachers more frequently and exchange ideas ( $\mathrm{f}=4$ ). The participant coded ÖE5 expressed the effectiveness of having planned and routine meetings as follows: "Faculty 
members and teachers should come together and hold planning and evaluation meetings at the beginning and end of the semester. I think that forced school visits that are not functional and realistic are not effective in the process". Faculty members stated that it would be beneficial to organize joint events $(\mathrm{f}=2)$ to ensure consensus among institutions. Similarly, they stated that joint activities $(\mathrm{f}=1)$ and seminars $(\mathrm{f}=1)$ between university and school would increase cooperation. Also, they stated that there was no effective communication ( $\mathrm{f}=3$ ) between university and school.

\subsubsection{Faculty members' evaluation methods for pre-service teachers' teaching practices}

Faculty members stated that they wanted a portfolio file containing a weekly lesson plan and report on teaching practices from pre-service teachers. The faculty members' evaluation methods for pre-service teachers were mostly based on observation $(\mathrm{f}=4)$. The portfolio files were prepared by preservice teachers $(f=3)$, the attendance $(f=1)$, the teachers' views in the practice schools $(f=1)$, and the criteria in the MoNE evaluation system $(\mathrm{f}=1)$.

\section{Discussion and Conclusion}

There are study results that reveal that school principals have an indifferent and authoritarian attitude regarding the practice processes (Bilgin-Aksu \& Demirtaş, 2006; Koç \& Yıldız, 2012). The meetings of all related parties to reach a common decision about the attitude to be displayed towards pre-service teachers, the practice procedures, and general planning will prevent such problems. Consistent with these views in the literature, it is concluded that pre-service teachers have expectations of being accepted and respected as a colleague by the school management, the practice teacher, and the faculty member.

It is seen that pre-service teachers expect school management in practice schools to inform them about the implementation and evaluation process of MoNE. Also, they want clear and regular information meetings to be held. In fact, they expect all parties of the process to participate in these meetings, and to adopt a common plan and attitude.

Pre-service teachers expect practice teachers to share their professional experiences about planning the lesson and communication with students and parents, support their professional development, and guide them. Also, pre-service teachers expect the practice teachers to effectively give feedback and evaluate the process. In this context, pre-service teachers emphasize the importance of practice teachers' observations, constructive criticism, and suggestions in the teaching process. Preservice teachers do not find it appropriate for some practice teachers to criticize them by interrupting their lecturing. Interrupting the lecture of the pre-service teachers in this way will prevent the students in the classroom from perceiving them as a teacher, from communicating positively, and also negatively affect the pre-service teachers' perceptions of their own proficiency.

Another important result is that some practice teachers go out of the classroom while the preservice teachers are lecturing. Pre-service teachers expect teachers to observe and give feedback. In different studies, it was also concluded that some practice teachers' guidance skills were insufficient for pre-service teachers. The fact that pre-service teachers start seeing themselves as professionally inadequate after teaching practice leads to the conclusion that the teaching practice processes carried out in the context of university-school cooperation should be reconsidered (Aydın, Selçuk \& Yeşilyurt, 2007). The different findings of this research gave consistent results. For example, while pre-service teachers criticized the practice teachers in terms of giving feedback and evaluation, practice teachers also stated that they wanted to receive education regarding this process. Results of other studies in the literature suggest that the practice teachers do not work by the purpose to develop pre-service teachers and do not give constructive feedback about their practices (Aydın, Selçuk \& Yeşilyurt, 2007; Baştürk, 2009; Bektaş \& Can, 2019; Çelik \& Gül, 2018; Eraslan, 2008; Gökçe \& Demirhan, 2005; Özmen, 2008; Paker, 2008). It is known that pre-service teachers need effective feedback and support from the practice teacher or faculty member in the planning phase of the lessons (Bektaş \& Can, 2019; Paker, 2008). Also, it is found that practice teachers behave indifferently towards pre-service teachers, display a negative attitude and are insufficient in guiding them (Aytaçl1, 2012; Bektaş \& Can, 2019; Koç \& Yıldız, 2012; Seçer, Çeliköz \& Kayıl1, 2010; Yılmaz, 2011). In this case, it may be necessary for practice teachers to receive training on this process. Because it is known that teachers at practice schools 
have an impact on the development of pre-service teachers on many different aspects (Australian Curriculum, Assessment, and Reporting Authority, 2019; Gökçe \& Demirhan, 2005; Rhoads, Samkoff \& Weber, 2013; Rozelle \& Wilson, 2012; Weasmer \& Woods, 2003). For this reason, it is thought that the effectiveness of practice teachers will be effective in training pre-service teachers as qualified teachers.

It is concluded that the most important expectation of the pre-service teachers from faculty members is to observe the process more frequently, establish communication and interaction between the institutions in all respects. It is concluded that faculty members frequently collected portfolio files/reports to evaluate the teaching practice of pre-service teachers. Pre-service teachers expect the faculty members to observe and evaluate them personally. In cases where it is not possible to make observations, pre-service teachers expect their performances to be evaluated by micro-teaching through video recording. Similar results have been encountered in other studies in the literature. For example, in a study, pre-service teachers stated that the theoretical dimensions of teaching practice courses expected to be carried out were not carried out regularly (Aslan \& Sağlam, 2018). In this context, preservice teachers are expecting to lecture under the observation of faculty members and receive feedback. Also, they expect to develop materials for the courses, use different teaching methods and techniques while teaching, make assessment and evaluation studies such as preparing and evaluating exams in the theoretical courses at the university. In the state of Bavaria, Germany, every student holds a seminar with the responsible faculty member at the university regarding their studies before and after each practice session at school (Çetin, Uludağ \& Akın, 2007). Thus, the pre-service teacher has the opportunity to share positive and negative experiences during the application that week, to exchange ideas, and to plan for the next practice with the faculty member.

The most important expectation of pre-service teachers from the university is to increase the number and duration of applied courses related to teaching. In many studies in the literature, it is stated that pre-service teachers' practices are insufficient (Aslan \& Sağlam, 2018; Aydın, Selçuk \& Yeşilyurt, 2007; Aytaçl1, 2012; Azar, 2003; Özkan, Albayrak \& Berber, 2005). This result is discussed in more detail in the section which includes the results regarding the expectations of practice teachers.

It is concluded that another important expectation of pre-service teachers from the university is to provide transportation support. Students expect to practice in schools that are suitable for them in terms of transportation. Transport shortages can be a problem in relatively large cities. Considering the frequency and time intervals of public transportation in small cities, it is only natural that pre-service teachers draw attention to this common problem. This issue was also discussed in similar studies conducted in Turkey. It is concluded that pre-service teachers have transportation difficulties while going to and returning from practice schools (Aydın, Selçuk \& Yeşilyurt, 2007; Çelik \& Gül, 2018; Erdem \& Erdoğan, 2012; Seçer, Çeliköz \& Kay1l, 2010). Various agreements can be arranged between universities and municipalities to eliminate this situation.

Practice teachers expect teachers and faculty members to meet and exchange information during the seminar periods. Also, practice teachers state that they have some expectations from MoNE. They think that the in-service training organized by the MoNE should be more functional in terms of the fields that teachers are interested in and needed. Practice teachers, who are involved in one dimension of the professional training of pre-service teachers, are required to receive planned, regular and systematic training to provide qualified guidance to pre-service teachers (Baştürk, 2010; BilginAksu \& Demirtaş, 2006; Çelik \& Gül, 2018; Özkılıç, Bilgin \& Kartal, 2008; Kudu, Özbek \& Bindak, 2006; Zachary, 2002). Because the ability of pre-service teachers to have an effective practice process depends on the quality of practice teachers, not the richness of resources in school or other opportunities (Kasapoğlu \& Yıldırım, 2018). It is revealed that teachers who carry out the teaching profession are willing to contribute to teacher training programs at universities as a guest, part-time or full-time (Mason, 2013).

Faculty members in the study evaluate the communication and cooperation between school and university as insufficient. In this context, they are expecting to meet to increase cooperation and communication among institutions and joint decision-making and common attitude. In the study where Escalie and Chalies (2016) investigated the contributions of university-school cooperation to preservice teachers, it was concluded that this cooperation is not always included in teacher education.

\section{Suggestion for Future Research}


According to the results of the research, it is found that ensuring the effective participation of all parties, establishing effective communication channels, and developing common planning and attitudes through the exchange of views are seen as the most basic needs. In this direction, it is deemed necessary for faculty members to meet more with the practice schools, exchange ideas, plan and evaluate together. To achieve this, it is recommended to adjust the course loads, academic and administrative responsibilities and to develop applicable methods. In this context, different applications can be designed with the models used in teacher training mentioned in the introduction of the research or a new model can be developed. From a renewed university-school cooperation perspective, it is recommended that university and practice schools come together in less hierarchical ways based on interaction, co-decision, and effort (Zeichner, 2010).

It should be ensured that practice teachers are supported with scientific activities by their interests and need to increase their proficiency. Also, training should be planned for practice teachers to have the equipment for guiding pre-service teachers, and practice teachers should be selected and appointed from among volunteers who attended these training. This will change the perspective of preservice teachers on practice teachers and will enable them to get more efficiency from the process. It is known that such training for practice teachers has very positive effects on teachers and pre-service teachers (Bektaş \& Can, 2019). It is recommended to increase the number and duration of teaching practice courses. Pre-service teachers facing real situations in schools and actively participating in teaching processes can be seen as an important step in training more qualified teachers.

\section{Co-Author Contribution}

The authors affirmed that there is no conflict of interest in this article. Mutlu Pinar Demirci Güler carried out the fieldwork, and overlook the writeup of the whole article. Sultan Selen Kula prepared the literature review, wrote the research methodology, and did the data entry. She carried out the statistical analysis and interpretation of the results.

\section{Acknowledgements}

The study was presented as an oral presentation at 2nd International Learning Teaching and Educational Research Congress between 6-9 September 2018, and only the abstract was published in the abstracts book. This research has been supported by Kırşehir Ahi Evran University Scientific Research Projects Coordination Unit. Project Number: EGT.A4.18.035

\section{References}

Akdemir, A. S. (2013). The history and problems of teacher training programs in Turkey. Turkish Studies International Periodical for the Languages, Literature, and History of Turkish or Turkic, 8(12), 15-28.

Arkün-Kocadere, S., \& Aşkar, P. (2013). A review of views about student teaching courses and an application model proposal. Hacettepe University Journal of Education, 28(2), 27-43, from https://avesis.hacettepe.edu.tr/yayin/70e0c8f2-7f55-475f-92b7-57e080f6dc91/a-review-ofviews-about-student-teaching-courses-and-an-application-model-proposal

Aslan, M., \& Sağlam, M. (2018). Evaluation of teaching practice course according to opinions of student teachers. Hacettepe University Journal of Education, 33(1), 144-162, from https://earsiv.anadolu.edu.tr/xmlui/handle/11421/14790

Atmiş, S., (2013). Examining the opinions of the teachers of the classroom about their evaluation of the teaching practice process [Unpublished master's thesis]. Karadeniz Technical University.

Australian Curriculum, Assessment and Reporting Authority. (2019). Retrieved from https://www.myschool.edu.au

Aydın, S.; Selçuk, A., \& Yeşilyurt, M. (2007). The effect of School Experience II on pre-service elemantary teachers: Yuzuncu yil university sample. Yüzüncü Yıl University Journal of Education Faculty, IV(II), 75-90. 
Aytaçl1, B. (2012). Evaluation of school experience and teaching practice course in elementary mathematics education undergraduate program [Unpublished master's thesis]. Ege University.

Azar, A. (2003). Reflections of views on school experience and teaching practice. Milli Ë̆itim Dergisi, $159,181-194$

Baştürk, S. (2009). Investigating teaching practice course according to student teachers' opinions. Elementary Education Online, 8(2), 439-456, from https://www.semanticscholar.org/paper/Investigating-Teaching-Practice-CourseAccording-toBa\%C5\%9Ft\%C3\%BCrk/c8c7c63bb0483656a165132f680ac61deecf2014?p2df

Baştürk, S. (2010). According to mentor teachers the group of school experience courses and teacher candidates. Journal of Turkish Educational Sciences, 8(4), 869-894.

Bektaş, M. \& Can, A. A. (2019). Equipping the Classroom Teachers with Mentorship Tasks and Responsibilities. Education and Science, 44(200), 23-45, from https://www.researchgate.net/profile/Asena_Ayvaz_Can/publication/336901095_Equipping_the _Classroom_Teachers_with_Mentorship_Tasks_and_Responsibilities/links/5de51e744585159a a45c9552/Equipping-the-Classroom-Teachers-with-Mentorship-Tasks-and-Responsibilities.pdf

Bilgin-Aksu, M. \& Demirtaş, H. (2006). Opinions of studentteachersupon School Experience II course (A sample of Educational Faculty at Inonu University). Inonu University Journal of Faculty of Education, 7(11), 3-21, from https://pegem.net/dosyalar/dokuman/8286-2011062816339aksudemirtas.pdf

Boreen, J. (2009). Mentoring beginning teachers: Guiding, reflecting, coaching. Stenhouse Publishers.

Creswell, J.W. (2015). Qualitative Research Methods. (M. Bütün \& S. B. Demir Translate Ed.), Ankara: Siyasal.

Çetin,Ö. F., Uludağ, E., \& Akın, M. (2007). The similarities and differences between school applications of educational faculty in Erzincan University and that of Ausburg University in Bavaria State. Erzincan Journal of Faculty of Education, 9(2), 159-166, from https://dergipark.org.tr/en/pub/erziefd/issue/6007/80096

Çelik, Y., \& Gül, İ. (2018). Evaluation of teaching practice course according to teacher candidate's opinions. Asian Journal of Instruction, 6(2), 81-103.

Edelfelt, R. \& Coble, C. (2004). University-school teacher education partnerships in North carolina. Journal of In-service Education, 30(3), 443-462, from https://www.tandfonline.com/doi/abs/10.1080/13674580400200250

Eraslan, A. (2008). A faculty-school partnership programme: Prospective mathematics teachers' reflections on school practice course. Hacettepe University Journal of Education, 34, 95-105.

Erdem, E. \& Erdoğan, Ü. I. (2012). Examination of teaching applications in terms of school and university cooperation: Chemistry education example. Hacettepe University Journal of Education, Special Issiue 1, 167-176.

Escalié, G., \& Chaliès, S. (2016). Supporting the work arrangements of cooperating teachers and university supervisors to beter train preservice teachers: a new theoretical contribution, European Journal of Teacher Education, 39(3), 302-319. https://doi.org/10.1080/02619768.2016.1185098

Gökçe, E., \& Demirhan, C. (2005). Teacher candidates and supervising teachers' opinions about activities of teaching practice in elementary schools. Ankara University Journal of Faculty of Educational Sciences, $\quad 1(38), \quad 43-71, \quad$ from https://dspace.ankara.edu.tr/xmlui/bitstream/handle/20.500.12575/46756/1037.pdf?sequence=1 \&isAllowed=y

Grudnoff, L.,Haigh, M., \& Mackisack, V. (2017). Re-envisaging and reinvigorating school-university practicum partnerships, Asia-Pacific Journal of Teacher Education, 45(2), 180-193. https://doi.org/10.1080/1359866X.2016.1201043

Healy, L.,Ehrich, L. C., Hansford, B., \& Stewart, D. (2001). Conversations: a means of learning, growth and change. Journal of Educational Administration, 39(4), 332-345. https://doi.org/10.1108/EUM0000000005494

Jianmei, X. \& Henk, H. Exploring a Qualitative Methods Approach to Measure Learning Gain in Teaching Assistants: A Chinese Case Study. Asian Journal of University Education, 16(3), 1-14. 
Kasapoğlu, K. (2015). A Review of studies on school experience and practice teaching in Turkey. Hacettepe University Journal of Education, 30(1): 147-162.

Kasapoğlu, K., \& Yıldırım, A. (2018). What difference does placement school make? Contribution of school characteristics to professional growth of pre-service teachers. Journal of Qualitative Research in Education, 6(1), 90-112. https://doi.org/410.14689/issn.2148-2624.1.6c1s4m

Koç, C., \& Yıldız, H. (2012). The reflectors of teaching experiences: diaries. Education and Science, $37(164)$ 221-236, from https://search.proquest.com/openview/44e5845275d69c6a0e411e33149a63dc/1?pqorigsite $=$ gscholar $\& \mathrm{cbl}=1056401$

Kudu, M., Özbek, R., \& Bindak, R. (2006). Students' perceptions of the School Experience-I: Dicle university sample. Elektronik Sosyal Bilimler Dergisi, 5(15), 99-109.

Lincoln, Y. S., \& Guba, E. G. (2013). The constructivist credo. California, CA: LeftCoastPress.

Maandag, D. W., Deinum, J. F., Hofman, A. W. H., \& Buitink, J. (2007). Teacher education in schools: an international comparison. European Journal of Teacher Education, 30(2), 151-173. https://doi.org/10.1080/02619760701275552

Mason, K. O. (2013) Teacher involvement in pre-service teacher education. Teachers and Teaching, 19(5), 559-574, https://doi.org/10.1080/13540602.2013.827366

MoNE (2017). Öğretmenlik mesleği genel yeterlikleri. Öğretmen Yetiştirme ve Geliştirme Genel Müdürlüğü. Ankara.

Merriam, S. B. (2013). Qualitative research: A guide to design and implementation (Translate Ed. S. Turan). Ankara: Nobel Publishing.

Merrill, M. D. (2002), First principles of instruction. Education Technology Researchand Development, 50 (3), 43-59, from https://link.springer.com/article/10.1007\%252FBF02505024

Miles, M. B., \& Huberman, A. M. (1994). Qualitative data analysis (2nd edition). Thousand Oaks, CA: Sage.

Özkan, H. H., Albayrak, M., \& Berber, K. (2005). The function of teaching application of prospective teachers in primary schools. Milli Eğitim Dergisi, 33(168).

Özkılıç, R., Bilgin, A., \& Kartal, H. (2008). Evaluation of teaching practice course according to opinions of teacher candidates. Elemantary Education Online, 7(3), 726-737, from http://ilkogretim-online.org.tr/index.php/io/article/download/1768/1604

Özmen, H. (2008). Student teachers' views on School Experience - I and - II Courses. Ondokuz Mayls University Journal of Faculty of Education, 25, 25-37.

Paker, T. (2008). Problems of student teachers regarding the feedback of university supervisors and mentors during teaching practice. Pamukkale University Journal of Education, 1(23), 132-139.

Rhoads, K., Samkoff, A., \&Weber, K. (2013). Student teacher and cooperating teacher tensions in a high school mathematics teacher internship: The case of Luis and Sheri. Mathematics Teacher Education and Development, 15, 108-128, from https://eric.ed.gov/?id=EJ1018596

Rozelle, J. J., \& Wilson, S. M. (2012). Opening the black box offield experiences: How cooperating teachers' beliefs and practices shape student teachers' beliefs and practices. Teaching and Teacher Education, 28, 1196-1205. https://doi.org/10.1016/j.tate.2012.07.008

Saka, M. (2019). Evulations of science teachers regarding the classes of school experience and teaching $\begin{array}{llll}\text { practices. Elemantary } \quad \text { Education } & \text { Online, 18(1), }\end{array}$ https://doi.org/10.17051/ilkonline.2019.527173

Seçer, Z., Çeliköz, N., \& Kayıl1, G. (2010). Problems in school practices in department of pre-school teaching and solution offers. Yüzüncü Yll University Journal of Faculty of Education, VII(I), 128152.

Toll, C. A., Nierstheimer, S. L., Lenski, S. D., \& Kolloff, P. B. (2004). Washing our students clean: Internal conflicts in response to preservice teachers' beliefs and practices. Journal of Teacher Education, 55, 164-176. https://doi.org/10.1177/0022487103261625

Weasmer, J., \& Woods, A. M. (2003). The role of the host teacher in the student teaching experience. The Clearing House, 76(4), 174-177. https://doi.org/10.1080/00098650309601998

Yıldırım, A., \& Şimşek, H. (2008). Sosyal bilimlerde nitel araştırma yöntemleri. Ankara: Seçkin Publishing. 
Y1lmaz, M. (2011). The opinions of primary school teacher candidates about the teaching staff lecturing teaching practice course. Gaziantep Üniversitesi Sosyal Bilimler Dergisi, 10(4), 1377-1387, from https://dergipark.org.tr/en/pub/jss/issue/24241/256986?publisher=gantep?publisher=gantep

Yin, R. K. (2003). Case study research: Design and methods. (2nd ed.). London: Sage.

HEB (2018). Sinı ögretmenliği lisans programi, from http://www.yok.gov.tr/documents/10279/41805112/Sinif_Ogretmenligi_Lisans_Programi.pdf

Zachary, L. J. (2002). The role of teacher as mentor. New Directions for Adult and Continuing Education, 93, 27-38, from http://www.norssiope.fi/norssiope/mentoring/aineistot/pdf_materials/zachary_role_teacher_men tor.pdf

Zanting, A., Verloop, N. \& Vermunt, J. D. (2001). Student teachers' beliefs about mentoring and learning to teach during teaching practice. British Journal of Educational Psychology, 71(1), 57 80. https://doi.org/10.1348/000709901158398

Zeichner, K. (2010). Rethinking the connections between campus courses and field experiences in college- and university-based teacher education. Journal of Teacher Education, 61(1-2), 89-99. https:/doi.org.10.1177/0022487109347671. 